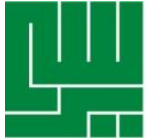

\title{
Acceptance \& Commitment Therapy (ACT) Kelompok untuk Meningkatkan Self-esteem pada Mahasiswa yang Mengalami Adiksi Media Sosial
}

\section{Group-Based Acceptance \& Commitment Therapy (ACT) \\ to Increase Self-esteem in University Students with Social Media Addiction}

\author{
Fina Dwi Putri, Fivi Nurwianti \\ Fakultas Psikologi Universitas Indonesia \\ Email:finadwip@gmail.com
}

KATA KUNCI

KEYWORDS

ABSTRAK

Acceptance and Commitment Therapy, Self-Esteem, Adiksi Media Sosial.

Acceptance and Commitment Therapy, Self-Esteem, Social Media Addiction.

Individu yang memiliki tingkat self-esteem rendah akan menunjukkan pychological inflexibility dalam menghadapi masalah dan menggunakan experiential avoidance sebagai bentuk penghindaran terhadap emosi negatif yang mereka alami. Di era pesatnya teknologi saat ini, media sosial menjadi bentuk experiential avoidance yang sering digunakan oleh mahasiswa. Dengan menggunakan acceptance and commitment therapy (ACT) diharapkan dapat membantu mahasiswa yang memiliki self-esteem rendah dan mengalami adiksi media sosial untuk meningkatkan psychological flexibility mereka. Penelitian ini menggunakan quasi-experimental one-group, pre-test and post-test design dan diikuti oleh lima partisipan yang merupakan mahasiswa/i berusia 19 - 21 tahun. Kelima partisipan memiliki skor self-esteem yang cenderung rendah berdasarkan alat ukur Rosenberg Self-Esteem Scale (RSES), mengalami adiksi media sosial yang diukur dengan Bergen Social Media Addiction Scale (BSMAS) dan penerimaan diri yang rendah diukur berdasarkan Acceptance and Action Questionnaire-II (AAQ-II). Intervensi yang dilakukan terdiri dari empat sesi dengan durasi sekitar dua jam per sesi. Sesi follow-up dilakukan satu minggu setelah empat sesi selesai dilakukan untuk melihat efek setelah intervensi diberikan. Data kualitatif didapatkan menggunakan wawancara tidak terstruktur sebelum, selama, dan sesudah intervensi diberikan. Data kuantitatif dianalisa menggunakan Wilcoxon Signed Ranks Test. Hasil menunjukkan bahwa intervensi berhasil secara signifikan meningkatkan perilaku penerimaan dan komitmen diri pada partisipan $(\mathrm{Z}=-2.023 ; \mathrm{p}=$ 0.043) yang diikuti dengan meningkatnya self-esteem pada diri partisipan $(Z=2.060 ; p=0.039 ; r=0.65)$. Tingginya nilai effect size $(r$ $\geq 0.50$ ) menunjukkan bahwa intervensi ACT berpotensi meningkatkan self-esteem. Selain itu, tingkat adiksi media sosial yang dimiliki partisipan juga mengalami penurunan meskipun tidak signifikan. 
ABSTRACT

Penelitian ini merekomendasikan ACT sebagai terapi yang efektif dalam mengatasi perilaku adiksi.

A person who has low self-esteem will show psychological inflexibility in handling problems and use experiential avoidance as a form of avoiding negative emotion which they experienced. During today's technological advancement era, social media became a method of experiential avoidance that often being used by university students. Using Acceptance and Commitment Therapy (ACT), students who have low self-esteem and social media addiction can gain benefit to improve their psychological flexibility. The research utilised one-group quasiexperimental, pre-test and post-test design and performed by five participants who are university students between 19 to 21 years old. These five participants tend to have low self-esteem according to Rosenberg Self-Esteem Scale (RSES) measurement, the social media addiction measured by using Bergen Social Media Addiction Scale (BSMAS), and low self-acceptance according to the Acceptance and Action Questionnaire-II (AAQ-II). The intervention consists of four sessions, with approximately two hours per session. The follow-up session organised to observe the result a week after finished four sessions of intervention. This research used qualitative data obtained from the unstructured interview before, throughout, and after the intervention has been provided. Wilcoxon Signed Ranks test was adopted to analyse the quantitative data. The result showed that intervention has been succeeded to significantly increase the acceptance behaviour and selfcommitment to the participants $(Z=-2.023 ; p=0.0 .43)$ followed by the increase of each participant's self-esteem $(Z=2.060 ; p=0.039 ; r=$ 0.65). A high score of effect size $(r \geq 0.50)$ showed that ACT has the potentials to increase self-esteem. Additionally, participants' social media addiction level was decreased yet insignificant. This research suggests that ACT is an effective therapy in resolving addiction behaviour.

\section{PENDAHULUAN}

Pada era berkembangnya teknologi dengan pesat, internet sudah menjadi suatu kebutuhan yang penting bagi individu secara pribadi karena kebanyakan kegiatan yang dilakukan di kehidupan sehari-hari tidak lepas dari peran internet. Dari semua bentuk kebutuhan terhadap internet, kebutuhan akan media sosial menjadi suatu fenomena umum yang paling menonjol pada individu. Pengguna internet di awal tahun 2020 telah mencapai lebih dari 4,5 miliar dan sebanyak 3,8 miliar menggunakan media sosial (Kemp, 2020). Frekuensi dan intensitas penggunaan media sosial mengalami peningkatan sejalan dengan semakin banyaknya fitur-fitur media sosial yang memfasilitasi berbagai bentuk kebutuhan psikologis dan sosial setiap individu. Media sosial membantu individu membagi informasi mengenai diri mereka, membentuk dan menjaga relasi sosial, dan menjadi tempat individu untuk bersenang-senang. Media sosial berorientasi pada pelayanan sosial, seperti profiling, mengunggah foto, menuliskan cerita dalam blog, dan berbagi, yang memunculkan kepuasan pada pengguna. Semakin lama dan dalam individu menggunakan media sosial maka semakin tinggi kesempatan mereka untuk memperluas jaringan dan membentuk relasi 
sosial (Hu, Kettinger, \& Poston, 2015). Dari hasil survey awal yang peneliti lakukan kepada mahasiswa Universitas Indonesia, terjaring 107 mahasiswa yang menunjukkan berbagai alasan mereka menggunakan media sosial diantaranya untuk mencari informasi, mencari hiburan, menghilangkan rasa bosan, dan untuk berkomunikasi. Durasi rata-rata yang mereka habiskan untuk menggunakan media sosial adalah selama kurang lebih 68 jam per hari.

Meskipun demikian, pada beberapa individu penggunaan media sosial menjadi lebih dari sekedar kebutuhan. Mereka melihat penggunaan media sosial sebagai suatu dorongan yang bersifat kompulsif dan menyita sebagian besar waktu di kehidupannya. Fenomena ini disebut sebagai ketergantungan atau adiksi terhadap media sosial. Adiksi terhadap media sosial adalah penggunaan media sosial secara berlebihan dengan intensitas tertentu hingga mengganggu kehidupan sehari-hari (Griffiths, dalam Hou, Xiong, Jiang, Song, \& Wang, 2019). Seseorang dapat dikatakan mengalami adiksi media sosial apabila mengalami preokupasi terhadap media sosial, menggunakan media sosial untuk mengurangi emosi negatif, terus menerus menggunakan media sosial untuk mendapatkan kesenangan, mengalami ketidaknyamanan apabila tidak menggunakan media sosial, memunculkan dampak negatif di kehidupan akibat penggunaan media sosial dan merasa dapat mengontrol penggunaan media sosial namun tidak berhasil (Andreassen, Pallesen, Griffiths, 2016).

Dari hasil survey awal kepada 107 mahasiswa Universitas Indonesia sebagaimana yang telah disebutkan, peneliti melakukan penjaringan kembali kepada mahasiswa yang merasa terganggu dengan penggunaan media sosialnya dan memenuhi kriteria terindikasi mengalami adiksi media sosial. Individu yang mengalami adiksi media sosial yaitu individu yang memiliki skor $\geq 19$ berdasarkan alat ukur Bergen Social Media Addiction Scale (BSMAS) yang merupakan alat untuk mengukur kecenderungan adiksi media sosial dalam kurun waktu satu tahun (Griffiths, dalam Hou dkk, 2019). Ditemukan setidaknya lima orang mahasiswa yang termasuk dalam kriteria adiksi media sosial. Tidak banyak proporsinya, namun data tersebut menunjukkan bahwa fenomenanya benarbenar ada.

Fenomena adiksi media sosial menjadi suatu hal yang penting untuk ditangani melihat dampak yang dirasakan oleh individu yang mengalaminya. Individu dengan adiksi media sosial seringkali tidak dapat mengontrol keinginannya untuk masuk dan menggunakan sosial media tersebut (Andreassen \& Pallesen, 2014). Berbagai studi menunjukkan gejala adiksi media sosial dapat ditunjukkan melalui masalah mood, reaksi fisik dan emosi, serta masalah interpersonal dan psikologis (Hou dkk, 2019). Menurut Griffiths (dalam Young \& De Abreu, 2011) terdapat enam kriteria adiksi media sosial diantaranya individu akan menggunakan media sosial sebagai coping terhadap suatu masalah, menganggap penggunaan media sosial merupakan aktivitas yag paling penting dalam kehidupan, adanya peningkatan intensitas pengaksesan media sosial secara bertahap, mengalami dampak negatif pada fisik maupun psikologis ketika akses ke media sosial dihentikan secara tiba-tiba, konflik terjadi di sekitar individu, dan kecenderungan individu untuk mengulang pola pengaksesan media sosial yang berlebihan sebelumnya dan kembali dengan pola yang lebih ekstrem setelah periode kontrol. Penggunaan media sosial yang intens ditemukan dapat memunculkan gejala depresi pada dewasa muda di United States (Lin, Sidani, Shensa, Radovic, Miller, Colditz, \& Primack, 2016).

Selain itu, penggunaan media sosial yang berlebihan juga dapat mempengaruhi performa akademik yang semakin menurun (Kirschner \& Karpinski, 2010). Pada survey yang peneliti lakukan, seluruh partisipan yang termasuk dalam kriteria 
adiksi mengeluhkan dampak negatif dan alasan menggunakan media sosial yang relatif sama. Kelima partisipan menyatakan bahwa penggunaan media sosial yang cukup lama dan tidak dapat mereka kontrol berdampak pada performa kuliah dan nilai akademis mereka.

Salah satu faktor yang dapat mendasari dampak negatif dari adiksi media sosial adalah self-esteem (Hou dkk, 2019). Sebagai contoh, banyak pengguna Facebook percaya bahwa orang lain (pengguna Facebook lain) memiliki hidup yang lebih bahagia dan sukses dibandingkan diri mereka sendiri (Chou \& Edge dalam Hou dkk, 2019). Self-esteem juga berasosiasi secara positif dengan performa akademik (Lane, Lane, \& Kyprianou dalam Hou dkk, 2019).

Berdasarkan survey yang peneliti lakukan, alasan partisipan menggunakan media sosial selain untuk menghilangkan rasa bosan atau sebagai distraksi tugas mereka adalah karena partisipan merasa dirinya kurang percaya diri dan menganggap media sosial sebagai tempat yang membuatnya dapat berinteraksi lebih nyaman. Partisipan juga menyatakan bahwa mereka sering merasa bahwa teman-teman yang mereka lihat di media sosial instagram memiliki hidup yang lebih bahagia dan menyenangkan dibandingkan hidup mereka.

Berdasarkan berbagai keluhan partisipan tersebut dapat terlihat gambaran self-esteem partisipan yang cenderung rendah dan merasa orang lain lebih baik dibandingkan diri mereka. Partisipan juga menjadikan media sosial sebagai pelarian akibat kurang nyamannya diri mereka ketika berinteraksi di dunia nyata. Dari penjelasan-penjelasan tersebut terlihat hubungan antara keadaan self-esteem dengan adiksi terhadap media sosial. Adiksi seseorang terhadap media sosial cenderung dipengaruhi oleh rendahnya selfesteem pada diri orang tersebut. Dengan demikian, peningkatkan self-esteem pada pecandu media sosial dapat menekan ketergantungan orang tersebut pada media sosial.

Meskipun demikian, belum banyak penelitian yang membahas bagaimana suatu intervensi kelompok dapat meningkatkan self-esteem demi mengurangi adiksi media sosial. Penelitian yang ada saat ini lebih banyak membahas mengenai kaitan antara self-esteem dan adiksi media sosial secara konseptual atau intervensi peningkatan selfesteem pada populasi non-adiksi media sosial (Andreassen, Pallesen, \& Griffiths, 2016; Kim \& Koh, 2018; Hou dkk, 2019). Meskipun demikian, belum banyak penelitian yang secara spesifik melihat efektivitas suatu intervensi peningkatan self-esteem pada pecandu media sosial.

Acceptance and commitment therapy (ACT) menjadi suatu bentuk intervensi yang menjanjikan sebagai solusi meningkatkan self-esteem. ACT merupakan terapi yang digunakan untuk membantu individu menerima seluruh aspek kehidupan dirinya tanpa terlibat dalam perilaku menghindar yang tidak perlu, serta mengembangkan pola aktivitas yang sesuai dengan nilai-nilai yang dimiliki (Hayes, Strosahl, \& Wilson dalam Hayes \& Levin, 2012). ACT menyasar pada faktor-faktor yang mempengaruhi rendahnya self-esteem diantaranya terkait belief dan pola pikir yang negatif, serta bagaimana individu dapat menerima emosi yang muncul dalam diri mereka.

Menggunakan intervensi acceptance and commitment therapy (ACT), diharapkan partisipan dapat mengembangkan fleksibilitas psikologis dan penerimaan terhadap dirinya. Dengan penerimaan diri yang meningkat maka diharapkan self-esteem individu juga dapat meningkat. Fleksibilitas psikologis yang berkembang melalui ACT mempengaruhi self-esteem individu untuk lebih merasa berdaya sehingga penyelesaian masalah yang dapat individu lakukan tidak kaku dan diharapkan dapat mengalihkan penggunaan media sosial yang berlebihan ke arah perilaku yang lebih positif. Selain itu, teknik mindfulness dalam ACT juga dapat 
membuat individu fokus dan rileks dalam menghadapi dampak dari pikiran dan perasaan yang tidak diinginkan (Hayes, Pistorello, \& Levin, 2012).

Penerapan ACT ini dilakukan pada setting kelompok yang diharapkan dengan bergabungnya partisipan-partisipan yang memiliki kondisi serupa maka akan terjadi normalisasi mengenai pengalaman negatif yang dialaminya (Turrell \& Bell, 2016). Dalam kelompok juga dapat terbentuk support system yang baru. Dalam terapi ACT, experiential avoidance, fusion, dan terputusnya individu dengan values yang dimiliki dapat sangat terlihat dalam setting kelompok (Eddins, 2014). Hal tersebut dikarenakan kelompok dapat membantu memberikan peluang individu untuk mau menunjukkan pengalaman, emosi negatif ataupun kerentanan yang dimiliki. ACT dalam kelompok juga terbukti dapat menurunkan experiential avoidance dan meningkatkan psychological flexibility (Takahashi, Ishizu, Matsubara, Ohtsuki, \& Shimoda, 2020; Fang \& Ding, 2020) yang menjadi target utama pada partisipan yang mengalami adiksi. Selain itu, penerapan ACT pada setting kelompok juga meningkatkan self-image yang lebih baik (Han, Liu, Su, \& Qiu, 2019) dimana hal ini merupakan hal penting untuk meningkatkan self-esteem individu.

Di dalam kelompok dengan latar belakang permasalahan yang serupa membuat individu merasa aman dan nyaman untuk berbagi pengalaman. Konteks kelompok juga dapat membantu individu dalam menumbuhkan motivasi untuk komitmen melakukan perubahan sesuai dengan values yang dimiliki serta komitmen yang dibuat di depan umum cenderung akan dilakukan. Hal tersebut sesuai dengan commited action yang merupakan kunci dari ACT.

Oleh karena itu, penelitian ini dilakukan untuk melihat efektivitas ACT kelompok dalam membantu meningkatkan self-esteem individu yang mengalami adiksi media sosial. Hasil penelitian ini dapat menjadi masukan dalam penerapan ACT dalam meningkatkan self-esteem pada individu yang mengalami adiksi media sosial. Setting terapi di dalam kelompok dilakukan untuk memaksimalkan output dari ACT. Secara teoritis, penelitian ini dapat memberikan masukan terkait hubungan antara konsep-konsept mindfulness dengan peningkatan selfesteem dan tingkat adiksi media sosial.

\section{METODE PENELITIAN Desain}

Penelitian ini menggunakan quasiexperimental one-group. Pengukuran dilakukan dengan model pre-test dan posttest serta follow-up setelah sesi intervensi selesai diberikan. intervensi dilakukan sebanyak empat sesi dengan durasi sekitar 150 menit per sesi.

\section{Partisipan}

Penelitian akan dilakukan kepada mahasiswa/i aktif program studi S1 Universitas Indonesia. Partisipan memiliki skor adiksi media sosial yang diukur dengan alat ukur BSMAS $\geq 19$ dan mengeluhkan dampak negatif dari penggunaan media sosial secara berlebihan hingga mengganggu kesehariannya. Selain itu, partisipan juga aktif mengakses medial sosial $\geq 6$ jam per hari.

\section{Setting dan Peralatan}

Kegiatan intervensi dilakukan di Fakultas Psikologi Universitas Indonesia. Peralatan yang digunakan yaitu modul intervensi yang akan diisi oleh partisipan bersama selama intervensi dan power point untuk membantu visualisasi materi.

\section{Prosedur}

Partisipan dijaring melalui kuesioner online sesuai dengan sasaran terapi kelompok. Setelah partisipan terjaring melalui kuesioner online, peneliti mewawancarai masing-masing partisipan untuk mendapatkan partisipan yang terindikasi memiliki self-esteem yang rendah. Partisipan diasumsikan memiliki self-esteem yang rendah ketika mereka 
menggunakan media sosial sebagai pelarian dari ketidaknyamanan mereka ketika berinteraksi langsung dengan dunia nyata. Dari hasil wawancara didapatkan lima partisipan yang menyatakan bahwa mereka merasa lebih nyaman berinteraksi atau menggunakan media sosial dibandingkan berinteraksi langsung dengan lingkungan sekitarnya. Selain itu, terdapat pula partisipan yang menyatakan langsung bahwa dirinya memiliki kepercayaan diri yang rendah karena membandingkan kehidupannya dengan orang lain di media sosialnya.

Pelaksanaan intervensi kelompok akan dilakukan sebanyak 4 sesi dan melakukan post-test setelah intervensi dilakukan. Follow up dilakukan satu minggu setelah sesi intervensi selesai diberikan untuk melihat efektivitas intervensi. Alat ukur yang digunakan dalam penelitian ini yaitu Rosenberg Self-Esteem Scale (RSES), Bergen Social Media Addiction Scale (BSMAS) dan Acceptance and Action Questionnaire-II (AAQ-II). RSES digunakan untuk mengukur tingkat selfesteem partisipan. Alat ukur RSES telah diadaptasi ke dalam bahasa Indonesia oleh Della (dalam Hutahaean, 2012) dengan diujikan pada 45 siswa SMP di Jakarta dan didapatkan konsistensi internal Cronbach's Alpha sebesar 0,706 yang artinya alat ukur ini konsisten dalam mengukur self-esteem seseorang. BSMAS digunakan untuk mengukur kecenderungan adiksi media sosial pada individu dalam kurun waktu satu tahun (Andreassen, Torsheim, Brunborg, \& Pallesen, 2012). AAQ-II dikembangkan oleh Bond, Hayes, Baer, Guenole, Waltz, Carpenter, Orcutt, \& Zettle (2011) yang digunakan untuk mengukur tingkat penerimaan individu terhadap masa lalunya, emosi dalam kehidupan yang dirasakan, dan sejauh apa individu dapat hidup sesuai dengan nilai-nilai yang dimilikinya. Alat ukur AAQ-II telah diadaptasi ke dalam Bahasa Indonesia oleh Permadi (2018) dan menghasilkan konsistensi internal Cronbach's Alpha sebesar 0,918 yang menunjukkan alat ukur ini reliabel.

Intervensi dilakukan sesuai rencana yaitu sebanyak empat sesi dengan kelima partisipan yang selalu hadir di setiap sesinya. Partisipan terlihat komit dan cukup atentif dalam mengikuti setiap sesi intervensi. Intervensi dilaksanakan setiap pukul 16.00 hingga selesai.

\section{Rancangan Program Intervensi}

Program intervensi dibagi menjadi empat sesi yang masing-masing sesinya berlangsung selama kurang lebih 150 menit. Sesi pertama digunakan untuk berbagi seluruh pengalaman partisipan terkait adiksi media sosial, psikoedukasi self-esteem dan penjabaran mengenai ACT. Tujuan dari sesi pertama yaitu untuk mendorong partisipan saling bercerita mengenai pengalaman mereka dalam menggunakan media sosial dan dampaknya bagi kehidupan mereka sehingga muncul rasa empati antar partisipan dan terbentuknya kepercayaan kelompok.

Partisipan juga diharapkan mampu memahami konsep ACT dan kaitannya dalam peningkatan self-esteem yang akan berdampak pada intensitas penggunaan media sosial mereka. Sesi pertama lebih banyak diisi dengan metode lecturing dalam pemberian psikoedukasi dan sharing antar partisipan dengan satu per satu menceritakan pengalamannya. Partisipan juga mengisi modul yang sudah diberikan untuk membantu melatih pemahaman mereka mengenai konsep ACT dan mengenali emosi terkait perilaku adiksi media sosial mereka.

Sesi kedua mulai melatih skill ACT mengenai choice point dan value. Tujuan sesi ini yaitu membuat partisipan mampu mengenali jerat pikiran yang membuat mereka ketergantungan terhadap media sosial. Partisipan juga memahami value hidup yang mereka miliki sehingga mulai terbentuk fleksibilitas psikologis yang membuat mereka memiliki lebih banyak pilihan hidup yang produktif. Sesi ini dilakukan dengan mengisi modul yang telah 
disediakan dan simulasi cerita dari masingmasing partisipan sehingga mereka dapat saling menanggapi dan memahami lebih dalam terkait materi yang diajarkan.

Sesi ketiga partisipan dilatih untuk lebih fokus pada sini kini dengan mengajarkan skill mindfulness. Tujuan dari sesi ini adalah untuk membuat partisipan lebih paham dan menyadari kondisi diri mereka sehingga dapat lepas dari perilaku adiksi yang mengganggu kehidupan mereka selama ini. Partisipan dipandu untuk berlatih teknik-teknik mindfulness selama sesi berlangsung dan kemudian berbagi pengalaman atau perasaan mereka selama berlatih teknik mindfulness.

Sesi terakhir partisipan diajarkan untuk dapat menerima seluruh kondisi diri mereka dan membuat commited action yang akan dilakukan partisipan setelah seluruh sesi intervensi berakhir. Tujuan sesi terakhir ini adalah untuk membuat partisipan paham mengenai siklus yang membuat individu mengalami self-esteem yang rendah dan siklus perilaku adiksi sehingga partisipan dapat benar-benar paham apabila kondisi tersebut kembali muncul dalam kehidupan mereka. Partisipan juga membuat action plan sesuai dengan value hidup mereka sehingga diharapkan partisipan tidak lagi hanya berfokus pada media sosial. Pada sesi terakhir ini metode intervensi lebih banyak menggunakan metode lecturing dan juga sharing antar partisipan. Partisipan juga saling membantu dalam pembuatan action plan sehingga masing-masing partisipan lebih dapat berkomitmen untuk menjalankan action plan yang telah mereka buat.

\section{Teknik Analisis Data}

Data yang didapatkan dianalisa menggunakan Wilcoxon Signed Ranks Test dengan program aplikasi IBM SPSS 24.0 for Windows yang bertujuan untuk melihat efektivitas ACT dalam meningkatkan selfesteem pada mahasiswa yang mengalami adiksi media sosial melalui perubahan skor yang terjadi pada partisipan antara pre-test dan post-test.

\section{ANALISIS DAN HASIL}

Hasil skor diperoleh dari kelima partisipan dengan inisial NI, IM, AA, CI dan MR. Berdasarkan hasil pada gambar 1, melalui alat ukur RSES dapat dilihat bahwa IM dan MR tergolong memiliki self-esteem yang rendah (cut off 15), NI dan CI cukup memiliki self-esteem yang baik dan AA memiliki self-esteem yang baik. Setelah dilakukan intervensi, terlihat pada skor RSES post-test seluruh partisipan mengalami kenaikan skor yang menandakan naiknya tingkat self-esteem mereka. Pada skor follow-up, skor RSES seluruh partisipan juga cenderung masih sama dengan skor saat post-test.

Untuk skor BSMAS, NI, IM, AA dan MR terindikasi mengalami adiksi media sosial yang sudah mengganggu kehidupannya (cut off 18), sedangkan CI memiliki skor 17 yang tergolong hampir menuju ke arah adiksi media sosial. Skor post-test BSMAS menunjukkan tiga partisipan, kecuali AA dan CI, mengalami penurunan skor yang menandakan tingkat adiksi media sosial mereka juga mulai berkurang, sedangkan CI masih pada kondisi yang sama dan AA justru mengalami sedikit peningkatan skor. Pada skor follow-up juga terlihat bahwa skor kelima partisipan juga masih relatif sama dengan skor post-test.

Selanjutnya untuk nilai AAQ-II, seluruh partisipan berada pada kategori tingkat penerimaan diri yang kurang dengan cut off 27-28. Setelah post-test dilakukan, seluruh partisipan menunjukkan penurunan skor yang cukup signifikan yang menandakan penerimaan diri mereka semakin meningkat. Pada saat follow-up, skor AAQ-II seluruh partisipan juga masih cenderung sama dengan skor post-test mereka. 


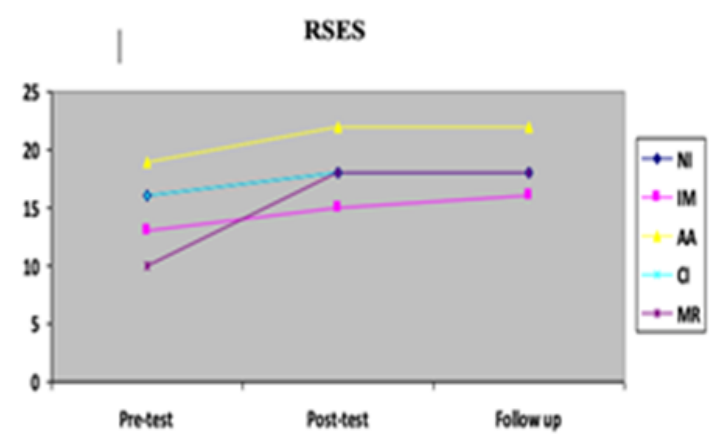

BSMAS

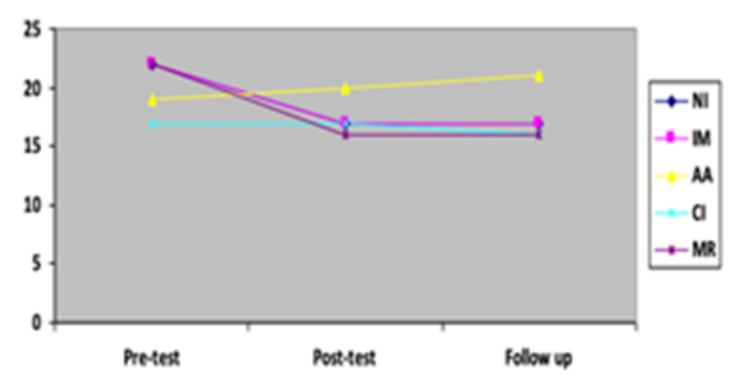

AAQ-II

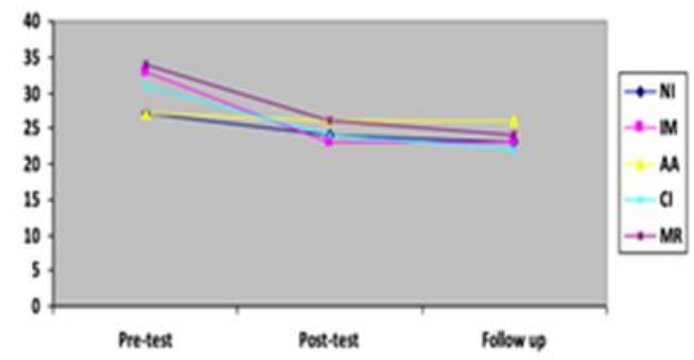

Gambar 1. Hasil pre-test, post-test dan follow-up.

Berdasarkan tabel 1 di bawah ini, dapat dilihat bahwa pemberian ACT dapat meningkatkan self-esteem partisipan dan meningkatkan penerimaan diri partisipan dengan signifikan $(p<.05)$. Di samping itu, ACT juga terlihat dapat menurunkan tingkat adiksi media sosial pada partisipan meskipun didapatkan hasil yang tidak signifikan $(p>.05)$. Dengan begitu, dapat dikatakan bahwa ACT dapat meningkatnya penerimaan terhadap diri yang juga berdampak pada meningkatnya self-esteem seseorang. Intervensi ACT yang diberikan kepada partisipan menghasilkan effect size yang cukup besar pada self-esteem $(r=.65)$ dan penerimaan dan komitmen $(r=.64)$ yang menunjukkan bahwa ACT memberikan dampak yang besar pada kedua variabel tersebut. Hal tersebut menandakan bahwa ACT dapat secara efektif meningkatkan self-esteem dan meningkatkan penerimaan diri seseorang. Selain itu, effect size yang dihasilkan pada adiksi media sosial tergolong sedang ( $r=$ .47) yang berarti ACT memiliki dampak yang cukup untuk menurunkan adiksi media sosial partisipan. 
Tabel 1

ACT untuk Meningkatkan Self-Esteem pada Mahasiswa yang Mengalami Adiksi Media Sosial

\begin{tabular}{cccc}
\hline Pengukuran & $\mathrm{Z}$ & p-value & Effect size $(r)$ \\
\hline $\begin{array}{c}\text { Self-Esteem (pre-test) } \\
\text { Self-Esteem (post-test) }\end{array}$ & $-2,060$ & $.039^{*}$ & .65 \\
\hline $\begin{array}{c}\text { Adiksi Media Sosial (pre-test) } \\
\text { Adiksi Media Sosial (post-test) }\end{array}$ & $-1,473$ & .141 & .47 \\
\hline $\begin{array}{c}\text { Penerimaan dan Komitmen } \\
(\text { pre-test) }\end{array}$ & $-2,023$ & $.043^{*}$ & .64 \\
\hline $\begin{array}{c}\text { Penerimaan dan Komitmen } \\
(\text { post-test) }\end{array}$ & & & \\
\hline
\end{tabular}

\section{DISKUSI}

Setelah mengikuti intervensi, seluruh partisipan mengalami peningkatan pada tingkat self-esteem dan penerimaan diri mereka. Hal tersebut dapat diartikan bahwa ACT terindikasi dapat membuat partisipan lebih menghargai diri dan menerima emosi negatif yang muncul dalam dirinya. Hal tersebut sesuai dengan target ACT yaitu tercapainya fleksibilitas psikologis sehingga individu dapat menerima seluruh aspek kehidupan dirinya tanpa terlibat dalam perilaku menghindar yang tidak perlu, serta mengembangkan pola aktivitas yang sesuai dengan nilai-nilai yang dimiliki (Hayes dkk, dalam Hayes \& Levin, 2012). Pada penelitian ini dapat terlihat bahwa dengan meningkatnya penerimaan diri partisipan maka mereka juga semakin menghargai dirinya yang berdampak pada peningkatan self-esteem mereka sehingga tingkat self-esteem yang baik tersebut kemudian berdampak pada menurunnya penggunaan media sosial di kehidupan mereka. Hal ini didukung oleh penelitian Randal, Pratt, \& Bucci (2015) yang menyatakan bahwa penerimaan diri (acceptance dalam terapi mindfulness) paling berkorelasi dengan peningkatan selfesteem seseorang. Selain itu, secara kualitatif partisipan menyatakan bahwa dengan mengikuti intervensi ini diri mereka menjadi dapat lebih fokus dan percara diri dalam menghadapi pekan ujian. Pola pikir yang positif membangun kepercayaan diri mereka dan membuat mereka lebih dapat mengontrol perilaku adiksi media sosialnya.

Di samping itu, selain empat partisipan yang mengalami penurunan pada tingkat adiksi media sosial, terdapat satu partisipan yaitu AA yang terlihat justru mengalami peningkatan dalam penggunaan media sosialnya saat diukur pada post-test hingga follow-up. Setelah dikonfirmasi kepada AA, ia mengakui bahwa penggunaan media sosialnya meningkat karena saat post-test dan follow-up dilakukan, pekan ujian telah selesai dan sudah tidak ada tugas yang harus ia kerjakan sehingga dirinya lebih bebas dalam menggunakan media sosial. Hal tersebut dapat dijelaskan bahwa penggunaan media sosial di masa saat ini merupakan hal yang esensial (Kuss \& Griffiths, 2017) sehingga sangat mungkin individu akan sering menggunakan media sosial di kehidupan sehari-hari mereka. Meskipun begitu, AA mengaku ketika pekan ujian ia dapat mengontrol penggunaan media sosialnya tersebut.

Dalam empat sesi intervensi kelompok yang dijalankan tentunya terdapat beberapa hal yang perlu disesuaikan dengan kondisi lapangan. Misalnya dalam hal penjadwalan dimana partisipan memiliki agenda yang berbedabeda sehingga perlu penyesuaian jadwal pertemuan yang harus dilakukan. Pada sesi pertama, partisipan tidak dapat hadir seluruhnya sehingga pertemuan sesi 
pertama dibagai menjadi dua yaitu NI, AA dan MR pada 26 April 2019, sedangkan IM dan CI mengikuti sesi susulan pada 30 April 2019.

Namun, pada sesi-sesi selanjutnya seluruh partisipan seperti memiliki komitmen untuk mengikuti intervensi kelompok bersama-sama sehingga didapatkan jadwal yang seluruh partisipan dapat hadir di waktu yang sama. Dalam pemberian modul juga sangat tergantung dari dinamika kelompok yang terjadi. Terdapat beberapa materi yang seluruh partisipan mudah memahami sehingga membutuhkan waktu yang singkat dan ada beberapa kegiatan dimana partisipan sangat antusias melakukan sharing sehingga diberikan jeda waktu yang lebih lama.

Selama berjalannya sesi, fasilitator juga tidak banyak memberikan ceramah dan lebih membangun penjelasan materi dengan cara yang interaktif. Fasilitator memberikan kesempatan untuk partisipan berdiskusi mengenai pemahaman mereka mengenai materi sehingga penjelasannya pun tidak satu arah. Secara umum, seluruh sesi dapat berjalan sesuai rencana dengan berbagai penyesuaian dan dengan kerjasama dari partisipan yang sangat baik. Komitmen dan antusiasme partisipan juga terjaga dengan baik hingga akhir sesi yang ditandai dengan tidak adanya partisipan yang gugur di tengah sesi dan keaktifan partisipan yang mereka tunjukkan selama sesi berlangsung.

Terkait kondisi self-esteem partisipan, setelah sesi intervensi selesai, tingkat self-esteem partisipan tidak terlalu banyak dipengaruhi oleh kondisi mereka yang sedang dalam pekan ujian. Terlihat dari hasil follow-up yang relatif stabil dengan hasil post-test. Hal tersebut dikarenakan tingkat self-esteem cenderung menetap pada diri seseorang dan dipengaruhi oleh pengalaman sepanjang hidup mereka dan bukan dari satu kondisi tertentu. Meskipun begitu, partisipan mengeluhkan ketakutannya akan adiksi media sosial yang mungkin dapat mempengaruhi performa mereka dalam menghadapi pekan ujian.
Penelitian sebelumnya yang dilakukan oleh Andreassen, Pallesen, \& Griffiths (2016) menyatakan bahwa, rendahnya self-esteem dapat mengarahkan individu pada perilaku adiksi media sosial sebagai bentuk pertahanan diri terhadap evaluasi diri yang negatif. Pada penelitian ini, secara kualitatif partisipan menyatakan bahwa pola pikir yang positif terhadap diri mereka membangun kepercayaan diri dan membuat mereka lebih dapat mengontrol perilaku adiksi media sosialnya. Dengan penggunaan media sosial yang terkontrol, kesiapan mereka menghadapi ujian pun meningkat. Partisipan menyatakan bahwa mereka menjadi dapat lebih fokus dan percara diri dalam menghadapi pekan ujian Adapun keterbatasan dalam penelitian ini diantaranya peneliti menggunakan teknik non-random sampling dimana partisipan yang diperlukan dipilih berdasarkan kriteria yang telah ditentukan dan berjumlah terbatas (Wojtys, Marra, \& Radice, 2018). Hal ini dapat membuat partisipan yang mengikuti intervensi tidak merepresentasikan dengan baik target populasi individu secara utuh dan hanya berlaku pada kasus spesifik. Selain itu, hasil yang didapatkan juga hanya menjadi preliminary evident pada efektivitas ACT dalam menangani adiksi media sosial dan lebih banyak memberikan masukan dalam teknis pelaksanaan terapi tersebut. Alat ukur BSMAS masih tergolong alat ukur baru yang belum terdapat reliabilitas dan validitasnya dan diagnosa adiksi media sosial pun belum terdapat dalam DSM-5 sehingga peneliti tidak dapat menentukan secara formal apakah individu mengalami adiksi media sosial.

\section{SIMPULAN}

Berdasarkan penelitian yang telah dilakukan maka dapat disimpulkan bahwa ACT pada kelompok dapat meningkatkan self-esteem yang dimiliki mahasiswa. Penurunan skor BSMAS pada empat partisipan mengindikasikan berkurangnya adiksi media sosial yang mereka alami. Selain itu, adanya peningkatan pada tingkat 
penerimaan diri partisipan terhadap diri mereka dan emosi-emosi yang mereka alami mengindikasikan penerimaan diri dan fleksibilitas psikologis partisipan meningkat.

\section{SARAN}

Dalam menerapkan ACT dalam setting kelompok terdapat beberapa langkah yang dapat dilakukan terlebih dahulu pada awal sesi terapi. Diantaranya, pada awal sesi perlu ditambahan ice breaking dalam pembentukan atau pengenalan masingmasing partisipan untuk membangun hubungan yang lebih dekat dan kepercayaan antar partisipan. Menambah durasi sesi sharing sehingga kebutuhan partisipan untuk didengarkan dan menumpahkan emosinya lebih dapat terwadahi. Metode yang lebih bervariasi juga dapat ditambahkan seperti game atau metode yang lebih interaktif untuk

\section{DAFTAR PUSTAKA}

Andreassen, C. S. \& Pallesen, S. (2014).

Social network site addiction-an overview. Current Pharmaceutical Design, 20, 4053-4061.

Andreassen, C. S., Pallesen, S., \& Griffiths, M. D. (2016). The relationship between addictive use of social media, narcissism, and self-esteem: Findings from a large national survey. Addictive Behaviour, 64, 287-293.

Andreassen, C. S., Torsheim, T., Brunborg, G. S., \& Pallesen, S. (2012). Development of a Facebook addiction scale. Psychological Reports, 110(2), 501-517.

Bond, F. W., Hayes, S. C., Baer, R. A., Guenole, N., Waltz, T., Carpenter, K, M., Orcutt, H. K., \& Zettle, R, D. (2011). Preliminary psychometric properties of the Acceptance and Action Questionnaire-II: A revised measure of psychological inflexibility and experiential avoidance. Behavior Therapy, 42(4), 676-688. mempermudah penyerapan materi dan membuat suasana terapi lebih nyaman. Terciptanya suasana yang dinamis dan kelompok yang saling berempati dapat mendukung tercapainya efektivitas ACT pada partisipan.

Bagi partisipan dapat terus melatih seluruh keterampilan-keterampilan yang diberikan selama sesi intervensi di berbagai aspek kehidupan mereka. Partisipan juga perlu berkomitmen untuk terus mengerjakan action plan yang telah mereka buat. Partisipan dapat terus saling menjalin komunikasi untuk menjadi tambahan support system bagi mereka dan membantu mengingatkan untuk melaksanakan action plan masing-masing. Partisipan juga perlu mampu mengenali gejala kekambuhan sehingga dapat secara sadar dan tepat menggunakan kemampuan relapse prevention yang telah diberikan saat sesi intervensi dengan segera.

Eddins, R. (2014). Acceptance commitment and therapy in group practice.Diakses https://hgps.org/newsletter/acceptanc e-commitment-therapy-in-grouppractice/.

Fang, S., \& Ding, D. (2020). The efficacy of group-based acceptance and commitment therapy on psychological capital and school engagement: A pilot study among Chinese adolescents. Journal of Contextual Behavioral Science, 16, 134-143.

Han, J., Liu, J., Su, Y., \& Qiu, H. (2019). Effect of a group-based acceptance and commitment therapy (ACT) intervention on illness cognition in breast cancer patients. Journal of Contextual Behavioral Science, 14, 73-81.

Hayes, S. C., \& Levin M. E. (2012). Mindfulness \& acceptance for addictive behaviors: Applying contextual CBT to substance abuse \& behavioral addictions. Oakland, CA: New Harbinger Publication, Inc. 
Hayes, S. C., Pistorello, J., \& Levin, M. E., (2012). Acceptance and commitment therapy as a unified model of behavior change psychology. The Counseling Psychologist, 40(7), 9761002.

Hou, Y., Xiong, D., Jiang, T., Song, L., \& Wang, Q. (2019). Social media addiction: Its impact, mediation, and intervention. Cyberpsychology: Journal of Psychosocial Research on Cyberspace, 13(1), 46-63.

Hu, T., Kettinger, W. J., \& Poston, R. S. (2015). The effect of online social value on satisfaction and continued use of social media. European Journal of Information Systems, 24(4), 391-410.

Hutahaean, B. S. H. (2012). Pelatihan untuk peningkatan self-esteem pada mahasiswa Universitas Indonesia yang mengalami distres psikologi (Tesis). Universitas Indonesia, Depok, Indonesia.

Kemp, S. (2020). Digital 2020: Global digital overview. Diakses dari https://datareportal.com/reports/digit al-2020-global-digital-overview.

Kim, E. \& Koh, E. (2018). Avoidant attachment and smartphone addiction in college students: the mediating effects of anxiety and self-esteem. Computer in Human Behavior, 84, 264-271.

Kirschner, P. A. \& Karpinski, A. C. (2010). Facebook ${ }^{\circledR}$ and academic performance. Computers in Human Behavior, 26, 1237-1245.

Kuss, D. J., \& Griffths, M. D. (2017). Social networking sites and addiction: Ten lessons learned. International Journal of Environmental Research and Public Health, 14(3), 311-327.

Lin, L. Y., Sidani, J. E., Shensa, A., Radovic, A., Miller, E., Colditz, J. B., \& Primack, B. A. (2016). Association between social media use and depression among US young adults. Depression and Anxiety, 33(4), 323331.

Permadi, D. (2018). Efektivitas pendekatan Mindfulness-Acceptance-

Commitment (MAC) terhadap penurunan tingkat kecemasan kompetitif pada atlet menembak tim Asean Armies Rifle Meet (AARM) TNI-AD (Tesis). Universitas Indonesia, Depok, Indonesia.

Randal, C., Pratt, D., \& Bucci, S. (2015). Mindfulness and self-esteem: A systematic review. Mindfulness, 6(6), 1366-1378.

Takahashi, F., Ishizu, K., Matsubara, K., Ohtsuki, T., \& Shimoda, Y. (2020). Acceptance and commitment therapy as a school-based group intervention for adolescents: An open-label trial. Journal of Contextual Behavioral Science, 16, 71-79.

Turrell, S. L., Bell, M. (2016). ACT for adolescent. Canada: Raincoast Books.

Wojtys, M., Marra, G., \& Radice, R. (2018). Copula based generalized additive models for location, scale and shape with non-random sample selection. Computational Statistic \& Data Analysis, 127, 1-14.

Young, K. S., \& De Abreu, C. N. (Eds.). (2011). Internet addiction: A handbook and guide to evaluation and treatment. New Jersey: John Wiley \& Sons, Inc. 